\title{
Preface
}

\section{National Basic Research Program of China (973 Program) Indo-Pacific Oceanic Channel Project Special Issue}

\author{
Guest editors \\ YUAN Dongliang (袁东亮) $)^{1, *}$, WU Qigang (吴其冈) $)^{2}$, CHEN Baode (陈葆德) ${ }^{3}$, \\ WANG Jianghai (王江海) ${ }^{4}$ \\ ${ }^{1}$ Institute of Oceanology, Chinese Academy of Sciences, Qingdao 266071, China \\ ${ }^{2}$ School of Atmospheric Science, Nanjing University, Nanjing 210023, China \\ ${ }^{3}$ Shanghai Typhoon Institute of CMA, Shanghai 200030, China \\ ${ }^{4}$ School of Marine Sciences, Sun Yat-Sen University, Guangzhou 510006, China \\ Received 16 Oct., 2017; Accepted 31 Oct., 2017 \\ (C) Chinese Society for Oceanology and Limnology, Science Press and Springer-Verlag GmbH Germany, part of Springer Nature 2018
}

\section{INTRODUCTION}

The tropical Indo-Pacific Oceans span over twothirds of the global tropical oceans. A major warm pool with the highest large-scale sea surface temperature of the global oceans is located in the western Pacific and eastern Indian Oceans. The climate systems over the tropical Pacific and Indian Oceans are subject to strong ocean-atmosphere coupling at multiple scales from intraseasonal to interannual, and to centennial. The strongest interannual variability of the global climate system, the El Niño and the Southern Oscillations (ENSO), is a result of the strong ocean-atmosphere coupling in the tropical Pacific Ocean. In addition, the tropical Indian Ocean is subject to the strong interannual variations associated with the Indian Ocean Dipole (IOD). The proximity of ENSO and IOD across the Indonesian maritime continent suggests that they interact with each other through the atmospheric bridge and/or the oceanic channel of the Indonesian Throughflow (ITF). These interactions between ENSO and IOD and their decadal to centennial variations have a strong impact on the East Asian Monsoon system.

Existing studies of the ENSO-IOD interactions have focused on the atmospheric bridge, i.e. the Walker Cell circulation over the tropical oceans. The interactions of the climate systems through the oceanic channel, i.e. the variations of the ITF, have been overlooked in the past. Recent studies suggest that ENSO can be predicted at the one year lead time if IOD is used as a precursor. The dynamics behind the connectivity and predictability have not been disclosed before and the general impact of this predictability on the Indo-Pacific climate variability has not been studied.

\section{INNOVATIVE STUDIES}

The papers published in this Global Change 973 (GC973 in abbreviation) special issue originate from the scientific researches funded by the National Basic Research Program of China (973 Program) of the Ministry of Science and Technology of China with the title "Response of the Ocean to Global Warming and their impact on China Marginal Sea Carbon Storage and East Asian climate" (ROME in abbreviation). The special issue contains 14 fulllength papers with the subjects of research covering the Indo-Pacific climate interactions, the cyclone studies in the northwestern Pacific, the Kuroshio and ecosystem studies in the East China Sea, and sediment analysis to understand the carbon storage in the marginal seas of northern China. Three of the papers

\footnotetext{
* Corresponding author: dyuan@qdio.ac.cn
} 
focus on the dynamics of the oceanic channel teleconnection governing the precursory relation between IOD and ENSO (Yuan et al., 2018, this issue), on the northwestern Pacific tropical cyclones modulated by Indo-Pacific sea surface temperature anomalies (SSTA) during super El Niños (Zhan et al., 2018, this issue), and on the Indo-Pacific SSTA influenced by two types of El Niño events (Hu et al., 2018, this issue); one paper studies the spatial and temporal variations of the Kuroshio east of Taiwan (Qi et al., 2018, this issue); three on the nutrient and ecosystem dynamics of the marginal seas $(\mathrm{Hu}$ et al., 2018; Wang et al., 2018; Zhang et al., 2018, this issue); five on the carbon storage in the bottom sediments in the Yellow and East China Seas (Lin et al., 2018; Wang et al., 2018; Xu et al., 2018a, b; Zhu et al., 2018, this issue); and two papers on the analyses of sediment samples collected in the Xisha Islands in the South China Sea and at a location south of the Shandong Peninsula in the Yellow Sea are also collected to understand the processes of carbon deposition (Qiu et al., 2018; Xu et al., 2018, this issue).

The influence of IOD on ENSO is an important aspect of the Indo-Pacific climate variations. The disclosed dynamics of the IOD-ENSO precursory relation associated with the ITF changes suggest the predictability of about half of the SSTA variability in the cold tongue associated with ENSO beyond the one-year lead time if IOD is used as a precursor (Yuan et al., 2018, this issue). The primary hypothesis is that the ocean upwelling off Java associated with IOD should propagate through the Indonesian seas to reach the western Pacific Ocean to impact ENSO evolution. The papers in this special issue have presented evidence of the IOD-ENSO interactions and predictability, which are innovative studies over the Indo-Pacific Ocean (Yuan et al., 2018, this issue).

While the papers collected in this special issue are somewhat not as thematic as in the 973 project, due to the high standard of the Journal of Oceanology and Limnology that has turned down a number of manuscripts during the review process, the proposed hypothesis is to study the carbon storage in the Yellow and East China Seas based on the disclosed connectivity and dynamics of the monsoon and ocean currents over the marginal seas. We take two approaches: one is to study the carbon storage carried by the cross-shelf currents into the subsurface of the Kuroshio; the other is to estimate the carbon storage directly from the sediment core samples over the shelf. The seven papers published in the GC973 special issue cover the second topic using the research methods of Cenozoic marine geology. All seven papers represent cutting-edge studies in their research fields. The first five papers focus on the centennialscale records and sequestration of sedimentary carbon in the East China Seas (Lin et al., 2018; Wang et al., 2018; Xu et al., 2018a, b; Zhu et al., 2018, this issue). The other two paper deals with the sediments in the Yellow Sea and in the northern South China Sea (Qiu et al., 2018; Xu et al., 2018, this issue). In particular, one paper reports the novel discovery of ferroan dolomites in Miocene sediments in Xisha Islands in the South China Sea (Xu et al., 2018, this issue). We expect these papers to become mainstream directions in their research fields in the near future.

\section{BACKGROUND}

The Chinese Journal of Oceanology and Limnology is the primary scientific journal in China publishing original research results related to physical, geological, and biogeochemical processes in the oceans and lakes. The journal has been included by the international Scientific Citation Institute as an SCI-E journal in 2008. The name of the journal is changed into Journal of Oceanology and Limnology since 2018. We are glad that this GC973 special issue has become the first publication of this prestigious journal with a new name.

Traditionally, the scientific papers published in the Chinese Journal of Oceanology and Limnology focus primarily on the research results in the marginal seas ofChina. As more and more climate-related researches are funded in China and in the surrounding countries, there is a high demand for a journal with readers of focused interests to publish new research results associated with the regional impact of global climate change. This has given an impetus to the newlynamed Journal of Oceanology and Limnology to organize a special issue related to climate variations and global change. Our GC973 special issue has come up at the right time.

\section{ACKNOWLEDGMENT}

We are very thankful for the support from Editor Roger $\mathrm{YU}$, who has organized this special issue. Thanks are also extended to the anonymous reviewers, who have made unselfish contributions to this special issue, and to the Ministry of Science and Technology of China for supporting the study of this special issue. 


\section{References}

Hu H B, Wu Q G, Wu Z P. 2018. Influences of two types of El Niño event on the Northwest Pacific and tropical Indian Ocean SST anomalies. Journal of Oceanology and Limnology, 36(1): 33-47, https://doi.org/10.1007/s00343018-6296-5.

$\mathrm{Hu}$ Y Y, Guo X Y, Zhao L. 2018. Interannual variation of nutrients along a transect across the Kuroshio and shelf area in the East China Sea over 40 years. Journal of Oceanology and Limnology, 36(1): 62-76, https://doi. org/10.1007/s00343-017-6234-y.

Lin J, Zhu Q, Hong Y H, Yuan L R, Liu J Z, Xu X M, Wang J H. 2018. Synchronous response of sedimentary organic carbon accumulation on the inner shelf of the East China Sea to the water impoundment of Three Gorges and Gezhouba Dams. Journal of Oceanology and Limnology, 36(1): 153-164, https://doi.org/10.1007/s00343-0176216-0.

Qi J F, Yin B S, Xu Z H, Li D L. 2018. Spatiotemporal variations of the surface Kuroshio east of Taiwan Island derived from satellite altimetry data. Journal of Oceanology and Limnology, 36(1): 77-91, https://doi. org/10.1007/s00343-018-6314-7.

Qiu J D, Liu J, Xu H, Zhou L Y. 2018. Sedimentary architecture of the Holocene mud deposit off the southern Shandong Peninsula in the Yellow Sea. Journal of Oceanology and Limnology, 36(1): 181-191, https://doi.org/10.1007/ s00343-018-7155-0.

Wang J H, Xiao X, Zhou Q Z, Xu X M, Zhang C X, Liu J Z, Yuan D L. 2018. Rates and fluxes of centennial-scale carbon storage in the fine-grained sediments from the central South Yellow Sea and Min-Zhe belt, East China Sea. Journal of Oceanology and Limnology, 36(1): 139152, https://doi.org/10.1007/s00343-017-6242-y.

Wang Y C, Guo X Y, Zhao L. 2018. Simulating the responses of a low-trophic ecosystem in the East China Sea to decadal changes in nutrient load from the Changjiang (Yangtze) River. Journal of Oceanology and Limnology,
36(1): 48-61, https://doi.org/10.1007/s00343-017-6233-z. Xu H, Zhang W W, Wei K, He Q K, Jiang Y S, Xu T T, Jiang X J, Yan G J, Song H Y, Wang J H. 2018. Ferroan dolomites in Miocene sediments of the Xisha Islands and their genetic model. Journal of Oceanology and Limnology, 36(1): 165-180, https://doi.org/10.1007/s00343-0187136-3.

Xu X M, Hong Y H, Zhou Q Z, Liu J Z, Yuan L R, Wang J H. 2018. Century-scale high-resolution black carbon records in sediment cores from the South Yellow Sea, China. Journal of Oceanology and Limnology, 36(1): 115-127, https://doi.org/10.1007/s00343-017-6214-2.

Xu X M, Zhu Q, Zhou Q Z, Liu J Z, Yuan J P, Wang J H. 2018. An improved method for quantitatively measuring the sequences of total organic carbon and black carbon in marine sediment cores. Journal of Oceanology and Limnology, 36(1): 105-114, https://doi.org/10.1007/ s00343-017-6229-8.

Yuan D L, Hu X Y, Xu P, Zhao X, Masumoto Y, Han W Q. 2018. The IOD-ENSO precursory teleconnection over the tropical Indo-Pacific Ocean: dynamics and long-term trends under global warming. Journal of Oceanology and Limnology, 36(1): 4-19, https://doi.org/10.1007/s00343018-6252-4.

Zhan R F, Chen B D, Ding Y H. 2018. Impacts of SST anomalies in the Indian-Pacific basin on Northwest Pacific tropical cyclone activities during three super El Niño years. Journal of Oceanology and Limnology, 36(1): 2032, https://doi.org/10.1007/s00343-018-6321-8.

Zhang Y F, Wang X T, Yin K D. 2018. Spatial contrast in phytoplankton, bacteria and microzooplankton grazing between the eutrophic Yellow Sea and the oligotrophic South China Sea. Journal of Oceanology and Limnology, 36(1): 92-104, https://doi.org/10.1007/s00343-018-6259-X.

Zhu Q, Lin J, Hong Y H, Yuan L R, Liu J Z, Xu X M, Wang J H. 2018. Centennial-scale records of total organic carbon in sediment cores from the South Yellow Sea, China. Journal of Oceanology and Limnology, 36(1): 128-138, https://doi.org/10.1007/s00343-017-6215-1. 